Agricultural Journal 5 (4): 269-272, 2010

ISSN: $1816-9155$

(C) Medwell Journals, 2010

\title{
Assessing Nutrient Potentials of a Soil Continuously Cropped with Xanthosoma sagittifolia (L) in Onisere Ondo State, Nigeria
}

\author{
J.O. Erhabor and W.A. Molindo \\ Department of Agriculture, Benson Idahosa University, P.M.B. 1100, Benin City, Edo State, Nigeria
}

\begin{abstract}
Field studies were carried out in Onisere, Ondo State, located between latitude $6^{\circ} 4^{1} \mathrm{~N}$ and longitude $5^{\circ} 1^{1} \mathrm{E}$ of South Western Nigeria. The aims were to assess the nutrients potentials of a soil continuously cropped with (cocoyams) Xanthosoma sagittifolia (L). The soil order is Alfisols developed from basement complex rocks and locally classified as Owo series of Ondo associations. The studies investigated the potentials of the soil to retain nutrients. Therefore, using this quality of the soil nutrient retention potential as a bench mark to encourage farmers to grow cocoyam continuously for a reasonable period without applying inorganic fertilizers. Randomly collected soil samples before and after planting during the cropping, seasons were subjected to laboratory analyses. The results showed significant $(\mathrm{p}=0.05)$ difference in soil $\mathrm{N}, \mathrm{P}, \mathrm{K}, \mathrm{Mg}$, $\mathrm{Ca}, \mathrm{Na}, \mathrm{OM}$ and $\mathrm{pH}$ within the period of continuous cropping. However, yield were not significantly $(\mathrm{p}=0.05)$ different but morphological parameters (leaves numbers, plants heights and stems girths) differ significantly $(\mathrm{p}=0.05)$ during the three seasons of continuous cropping. The experiment proved that the nutrients potentials of the soil sustained the continuous growth of cocoyam for a period of three cropping seasons. The potential nutrients retention of this soil was encouraged by its inherent nutrients and characteristics. Therefore, farmers may be advised to grow cocoyam in this soil without being apprehensive of inorganic fertilizer applications.
\end{abstract}

Key words: Assessing, nutrients, potentials, soil, cocoyam, Onisere, Nigeria

\section{INTRODUCTION}

The potentially inherent soil nutrients contributes significantly to plants performance and yields. When other factors (water, soil structure, texture and management organic/inorganic inputs) are enumerated native soil nutrients that is nutrients inherent by the soil are an inevitable factor. Agboola et al. (1999) reported that continuous cropping on the same soil lead to nutrient depletion. Cocoyam (Xanthosoma sagittifolia (L)) is suspected to demand more nutrients than cassava (Onwueme and Sinha, 1991).

Cocoyam thrives best in the humid tropics for its edible corms, cormets, leaves, young stems and its uses in traditional ceremonies. Also, it requires adequate moisture (2000 mm year ${ }^{-1}$ rainfall) average temperature (about $24 \%$ ) and its growth would be rapid in mature soils (Udoh et al., 2005; Onwueme and Sinha, 1991).

When grown as a sole crops yields increase appreciably (Terry et al., 1984). Udoh et al. (2005) reported that NPK fertilizers increased yields. However, local farmers are apprehensive about current high prices of fertilizers and prefer to grow the crop without applying fertilizers. Research therefore on the inherent nutrients of a soil to support cocoyam growth is inevitable. This study is therefore, anchored on this premise to assess the nutrients potentials of a soil under continuous cropping of cocoyam for three planting seasons. Hence, recommend to the local farmers to grow the crop continuously in this soil for about 3 planting season before applying fertilizers if at all needed. Hence, avoid the expected expenses that would had been incurred from the purchase of fertilizers.

\section{MATERIALS AND METHODS}

Experimental site: This was in Onisere, a farming village located on latitude $6^{\circ} 4^{1} \mathrm{~N}$ and longitude $5^{\circ} 1^{1} \mathrm{E}$ in Ondo State Southwestern Nigeria with a tropical rain forest climate. The annual rain fall ranges from $2320-2540 \mathrm{~mm}$, temperatures between $24-35^{\circ} \mathrm{C}$ and relative humidity from 70-100\% (Agboola, 1979).

The soil order is Alfisols developed on sedimentary metamorphic/igneous rocks of basement complex (Soil Survey Staff, 1999). Locally classified as Owo series of the Ondo association (Murdock et al.,

Corresponding Author: J.O. Erhabor, Department of Agriculture, Benson Idahosa University, P.M.B. 1100, Benin City, Edo-State, Nigeria 
1976). A brown clayey soil profile $0-30 \mathrm{~cm}$ depth with few quartz gravel stones and concretion is observed. Murdock et al. (1976) described the soil to be well drained and moderately good structured.

Soil analysis: The following parameters were analysed in the laboratory from a composite soil sampled from the site at a depth of $0-15 \mathrm{~cm}$. The soil was air dried, ground, passed through a $2 \mathrm{~mm}$ sieve and analysed for its physicochemical properties using standard laboratory procedures (Mylavarapus and Kennelley, 2002). The soil $\mathrm{pH}$ was determined using the procedure out lined by Mylavarapus and Kennelley (2002). The Walkey and Black and the wet dichromate oxidation (Nelson and Sommers, 1982) method was used to determine both organic carbon and matter, respectively.

The macro- kjeldahl (Bremner and Mulvaney, 1982) method was used to determine the soil total nitrogen. The nitrate-nitrogen was calorimetrically determined using the phenol -2 -4 disulforic acid method (Jackson, 1970). Available phosphorus by the Bray $\mathrm{P}_{1}$ method (Olsen and Sommers, 1982) and colour developed in the soil extract using the ascorbic acid method (Murphy and Riley, 1962). Exchangeable bases ( $\mathrm{K}, \mathrm{Na}, \mathrm{Ca}, \mathrm{Mg}$ ) were extracted with I N $\mathrm{NH}_{4} \mathrm{OAc}$ buffered at $\mathrm{pH} 7.0$ (Thomas, 1982).

The exchangeable $\mathrm{K}$ and $\mathrm{Na}$ were read on an EEL flame photometer. The $\mathrm{Ca}$ and $\mathrm{Mg}$ were read on an atomic absorption spectrophotometer. The Total Exchangeable Bases (TEB) was got by summation of the bases $(\mathrm{Na}, \mathrm{K}$, $\mathrm{Ca}, \mathrm{Mg}$ ). Exchangeable acidity was extracted with $\mathrm{I} \mathrm{N} \mathrm{KCl}$ (Thomas, 1982) and determined by titration with $0.05 \mathrm{~N}$ $\mathrm{NaOH}$ using phenolphthalein indicator. Effective cation exchange capacity was taken as the summation of bases $(\mathrm{K}, \mathrm{Na}, \mathrm{Ca}, \mathrm{Mg}$ ) and the exchangeable acidity (Chapman, 1965).

Experimental materials: The white flesh cocoyam cultivar that matures between 8-9 Months After Planting (MAP) and weighing about $100-120 \mathrm{~g}$ per sett was used as the propagating materials.

Land preparation: The land was manually cleared using native cutlass and matchets. The grasses and debris burnt leaving a bare surface that was not ploughed. Therefore, this experiment was conducted under zero tillage conditions.

Experimental design: It was a Completely Randomized Design (CRD) with three replicates. Each plot measured $9 \times 27 \mathrm{~m}^{2}$ giving a total area of $243 \mathrm{~m}^{2}$ surrounded by $1 \mathrm{~m}$ guard rows.

Field planting: The cocoyam were planted one corm per hill at $1 \times 1 \mathrm{~m}$ spacing on flat land without tillage of the soil. This gave a plant population of 243 plants/plot at
$1 \mathrm{corm} /$ hill. Udoh et al. (2005) had used 1.0-1.2 m apart that is similar to the one in his studies. Planting was done under rain fed system once every season.

Field maintenance: Control of weeds was done manually using native hoes and cutlasses at the fourth and eighth Weeks after Planting (WAP).

Date collection: The following parameters (Plants heights, leaves numbers, stems girths) were measured and recorded at 3 months intervals. Plants heights were measured using a metric ruler from the soil level to the tip of the last opened leaf. The initial leaf count was done by counting the leaves from base to the last opened leaf. This last opened leaf was then marked with a label.

About 3 months later, the number of leaves opened after the one previously marked was counted, recorded and the label transferred to the youngest leaf. This process was maintained through out the study period. Stems girths were measured using a string. The string was tied round the cocoyam stem at a height of $5 \mathrm{~cm}$ from the soil level. Measurements were done on 20 randomly tagged plants.

\section{RESULTS AND DISCUSSION}

Table 1 shows the physicochemical properties of the soil before cropping of Xanthosoma sagittifolia (L) in the field. The result showed that the soil was slightly acidic. The values for nutrients such as $\mathrm{N}=1.18 \mathrm{~g} \mathrm{~kg}^{-1}, \mathrm{P}=$ $8.23 \mathrm{mg} \mathrm{kg}^{-1}, \mathrm{~K}=0.30 \mathrm{cmol} \mathrm{kg}{ }^{-1}$ and $\mathrm{Mg}=2.10 \mathrm{cmol} \mathrm{kg}^{-1}$ indicated that the soil had a relatively good fertility when compared to the critical levels $\left(\mathrm{N}=1.50-2.00 \mathrm{~g} \mathrm{~kg}^{-1}\right.$ (Sobulo and Osiname, 1981); $\mathrm{P}=10.00-16.00 \mathrm{mg} \mathrm{kg}^{-1}$

Table 1: Physicochemical properties of the analyzed soil before Xanthosoma sagttifolia $(\mathrm{L})$ cropping

\begin{tabular}{|c|c|}
\hline Properties & Value \\
\hline Sand \% & 83.10 \\
\hline Silt \% & 8.70 \\
\hline Clay $\%$ & 8.20 \\
\hline $\mathrm{pH}\left(\mathrm{H}_{2} \mathrm{O}\right)$ & 6.70 \\
\hline $\mathrm{pH}\left(\mathrm{CaCl}_{2}\right)$ & 6.15 \\
\hline Organic-C $\mathrm{g} \mathrm{kg}^{-1}$ & 4.21 \\
\hline Organic-Mg kg ${ }^{-1}$ & 7.28 \\
\hline Total- $\mathrm{N} \mathrm{g} \mathrm{kg}^{-1}$ & 1.18 \\
\hline Nitrate- $\mathrm{N}+\mathrm{mg} \mathrm{kg}^{-1}$ & 7.60 \\
\hline $\mathrm{C}: \mathrm{N}$ ratio & 6.10 \\
\hline Available-P $\mathrm{mg} \mathrm{kg}^{-1}$ & 8.23 \\
\hline Exch.-K $\mathrm{cmol} \mathrm{kg}^{-1}$ & 0.30 \\
\hline Exch.-Ca $\mathrm{cmol} \mathrm{kg}^{-1}$ & 2.10 \\
\hline Exch.-Mg cmol kg ${ }^{-1}$ & 0.35 \\
\hline Exch.-Na $\mathrm{cmol} \mathrm{kg}^{-1}$ & 0.22 \\
\hline Total Exch. Basses (TEB) $\mathrm{cmol} \mathrm{kg}^{-1}$ & 2.97 \\
\hline Exch. Acidity $\mathrm{cmol} \mathrm{kg}^{-1}$ & 0.39 \\
\hline $\mathrm{ECEC} \mathrm{cmol} \mathrm{kg}^{-1}$ & 3.36 \\
\hline Textural class & SCL \\
\hline
\end{tabular}

$\mathrm{SCL}=$ Sandy Clay Loam 
Agric. J., 5 (4): 269-272, 2010

Table 2: Value of nutrients in the soil within the period of Xanthosoma sagittifolia $(\mathrm{L})$ continuous cropping

\begin{tabular}{|c|c|c|c|c|c|c|c|c|}
\hline \multirow[b]{3}{*}{ Properties } & \multicolumn{8}{|c|}{ Values of analysed nutrients } \\
\hline & \multicolumn{2}{|c|}{ 1st cropping } & \multicolumn{2}{|c|}{ 2nd cropping } & \multicolumn{2}{|c|}{ 3rd cropping } & \multirow[b]{2}{*}{$\overline{\mathrm{X}}$} & \multirow[b]{2}{*}{ LSD 5\% } \\
\hline & $\mathrm{BC}$ & $\mathrm{AC}$ & $\mathrm{BC}$ & $\mathrm{AC}$ & $\mathrm{BC}$ & $\mathrm{AC}$ & & \\
\hline $\mathrm{pH}\left(\mathrm{H}_{2} \mathrm{O}\right)$ & 6.70 & 6.50 & 6.60 & 6.45 & 6.50 & 6.40 & 6.53 & 0.49 \\
\hline $\mathrm{pH}\left(\mathrm{Ca} \mathrm{Cl}_{2}\right)$ & 6.15 & 6.00 & 6.10 & 5.90 & 6.00 & 5.50 & 5.94 & 0.59 \\
\hline Organic-C $\mathrm{g} \mathrm{kg}^{-1}$ & 4.21 & 4.10 & 3.79 & 3.30 & 2.90 & 2.55 & 3.48 & 1.69 \\
\hline Organic-M g kg${ }^{-1}$ & 7.28 & 7.09 & 6.55 & 5.76 & 5.01 & 4.41 & 6.02 & 2.93 \\
\hline Total-N g kg-1 & 1.18 & 1.12 & 1.10 & 1.09 & 1.07 & 1.01 & 1.10 & 0.14 \\
\hline C:N ratio & $6: 1$ & $6: 1$ & $6: 1$ & $5: 1$ & $5: 1$ & $4: 1$ & - & - \\
\hline Avail-P mg kg ${ }^{-1}$ & 8.23 & 6.13 & 7.90 & 7.00 & 6.70 & 6.10 & 7.10 & 2.26 \\
\hline Exch. $\mathrm{K} \mathrm{cmol} \mathrm{kg}{ }^{-1}$ & 0.30 & 0.29 & 0.27 & 0.24 & 0.22 & 0.20 & 0.25 & 0.02 \\
\hline Exch. $\mathrm{Ca} \mathrm{cmol} \mathrm{kg}^{-1}$ & 2.10 & 2.19 & 2.04 & 1.88 & 1.66 & 1.44 & 1.89 & 1.07 \\
\hline Exch. $\mathrm{Mg} \mathrm{cmol} \mathrm{kg}^{-1}$ & 3.35 & 0.34 & 0.32 & 0.30 & 0.28 & 0.25 & 0.31 & 0.10 \\
\hline Exch. Na cmol kg-1 & 0.24 & 0.22 & 0.20 & 0.17 & 0.18 & 0.15 & 0.19 & 0.08 \\
\hline TEB cmol kg-1 & 2.97 & 2.94 & 2.83 & 2.59 & 2.28 & 2.04 & 2.61 & 0.09 \\
\hline Exch. Acidity cmol kg${ }^{-1}$ & 0.39 & 0.36 & 0.30 & 0.27 & 2.04 & 0.19 & 0.29 & 0.19 \\
\hline $\mathrm{ECEC} \mathrm{cmol} \mathrm{kg}{ }^{-1}$ & 3.36 & 3.30 & 3.13 & 2.86 & 2.52 & 2.23 & 2.90 & 1.14 \\
\hline
\end{tabular}

$\mathrm{BC}=$ Before cropping; $\mathrm{AC}=$ After cropping

Table 3: Measured Xanthosoma sagittifolia (L) parameters (Leaves Numbers (LN), Plants Height (PH) and Plants Girths PG) cm at 3,6,9 MAP

\begin{tabular}{|c|c|c|c|c|c|c|c|c|c|c|c|}
\hline \multirow[b]{2}{*}{ Parameters } & \multicolumn{3}{|c|}{ 1st cropping } & \multicolumn{3}{|c|}{ 2nd cropping } & \multicolumn{3}{|c|}{ 3rd cropping } & \multirow[b]{2}{*}{$\bar{X}$} & \multirow[b]{2}{*}{ LSD $5 \%$} \\
\hline & 3 & 6 & 9 & 3 & 6 & 9 & 3 & 6 & 9 & & \\
\hline $\mathrm{LN}$ & 3.00 & 5.00 & 8.00 & 3.00 & 6.00 & 9.00 & 4.00 & 6.00 & 8.00 & 6.00 & 4.37 \\
\hline $\mathrm{PH}(\mathrm{cm})$ & 20.62 & 48.14 & 69.95 & 25.07 & 58.85 & 79.50 & 28.50 & 50.60 & 70.80 & 57.05 & 36.38 \\
\hline $\mathrm{PG}(\mathrm{cm})$ & 60.50 & 10.60 & 16.70 & 7.88 & 11.72 & 15.75 & 8.43 & 13.33 & 17.37 & 14.03 & 7.25 \\
\hline
\end{tabular}

LN = Leaves Numbers, $\mathrm{PH}=$ Plants Heights; $\mathrm{PG}=$ Plants Girths; $\mathrm{MAP}=$ Months After plantings

(Adeoye and Agboola, 1985); $\mathrm{K}=0.16-0.20 \mathrm{mg} \mathrm{kg}^{-1}$ (Hunters 1975); $\mathrm{Mg}=0.20-0.40 \mathrm{cmol} \mathrm{kg}^{-1}$ (Lombin, 1974) for South Western Nigerian soils. Hence, there was no need to apply any fertilizer.

Moreover, the experiment was aimed at finding whether this soil would sustain the continuous growth of Xanthosoma sagittifolia (L). The values of soil nutrients during continuous Xanthosoma sagittifolia cropping are shown in Table 2. There were slight changes in the overall soil nutrients when compared to their values before cropping season. No doubt continuous cropping of Xanthosoma sagittifolia (L) caused only small changes in N P K the major nutrients however, the growth performance of the crops were not significantly $(p=0.05)$ affected.

This was reflected in the yield values that were not significantly different within the years of continuous Xanthosoma sagittifolia (L) cropping. This might be due to the native nutrient contained in this soil. The ability of this soil to support the Xanthosoma sagittifolia (L) growth indicates and justifies the potential of this soil to retain nutrients. Although, the non-tillage of the land might had encouraged a low depletion of nutrients inherent in this soil.

Also, the nutrient values of the soil during the periods of continuous cropping as indicated in Table 2, showed no significant $(\mathrm{p}=0.05)$ difference in the nutrient regime measured before and after each cropping season. This qualified the nutrient refention capacity of the soil. It might be explained that processes such as leaching and
Table 4: Mean values of Xanthosoma sagittifolia (L) from the 1st, 2nd, 3rd cropping seasons

\begin{tabular}{lc}
\hline Cropping seasons & Mean yields \\
1st cropping. & 3.55 \\
2nd cropping & 3.70 \\
3rd cropping & 3.62 \\
Mean & 3.62 \\
LSD 5\% & 1.82 \\
\hline
\end{tabular}

depletion may not had been encouraged due to the fact that cocoyam (Xanthosoma sagittifolia (L)) crops forms a canopy due to its broad leaves. Therefore, the impact of rain drops on the soil surface is reduced. Hence, the washing down of nutrients within the soil might have been minimized. Also, the soil is not easily eroded may be due to its texture being a sandy clay loam which has a reasonable clay content as shown in Table 1.

The available-P supported the potential of this soil to retain nutrient because there was no significant $(\mathrm{p}=0.05)$ differences in this nutrient throughout the three years of continuous cropping. The measured morphological parameters (leaves numbers, plants heights, plants girths) are shown in Table 3 . There were significant $(\mathrm{p}=0.05)$ differences in leaves numbers during each cropping season. Similarly, plants heights and girths were significantly different within the cropping months of 3, 6, 9 after Planting (MAP) and between each cropping season. This was expected because the Xanthosoma sagittifolia (L) growth was observed from the initial month after planting to be robust. In general, a good morphological growth is a positive indication of better tuber formations. The corn yield of Xanthosoma sagittifotical (L) yield is shown in Table 4. 


\section{CONCULSION}

From the results, there was no significant $(\mathrm{p}=0.05)$ difference in the yields between the three cropping seasons. This might be due to the soil potential to retain nutrients sufficient to sustain the Xanthosoma sagittofilia (L) growth. If there was a depletion of nutrients probably the yields might had declined. Therefore, it might be confirmed that the continuous cropping of Xanthosoma sagittofilia (L) in this soil in Onisere be encouraged.

\section{RECOMMENDATIONS}

Farmers should therefore be advised to disabse their minds of being apprehensive because of impending expenses on/in organic fertilizers. Rather organic fertilizer application would be suggested to the farmers. In this study, dead leaves of Xanthosoma sagittofilia (L) dropping on the soil might had contributed to organic matter that encourage a nutrient build up and contribute to the potential retention of nutrients by the soil.

\section{REFERENCES}

Adeoye, G.O. and A.A. Agboola, 1985. Critical level for soil $\mathrm{pH}$, available $\mathrm{P}, \mathrm{K}, \mathrm{Zn}$ and $\mathrm{Mn}$ and maize earleaf content of $\mathrm{P}, \mathrm{Cu}, \mathrm{Zn}$ and $\mathrm{Mn}$ in sedimentary soils of Southwestern Nigeria. Nutr. Cycl. Agroecosyst., 6: 65-71.

Agboola, S.A., 1979. An Agricultural Atlas of Nigeria. Oxford University Press, New York, pp: 81-85.

Agboola, A.A., J.O. Olukosi, K.A. Elemo, B.F.D. Oko, H. Tijani-Eniola and N.U. Ndaeyo, 1999. Farming systems and appropriate agricultural land use in Nigeria. ProceedingS of the Meeting of the National Agricultural Land use and Management, Policy Evolution Committee, Ibadan, Sept. 28-30th, Ibadan, Nigeria.

Bremner, J.M. and G.S. Mulvaney, 1982. Nitrogen Total. In: Methods of Soil Analysis Part 2: Chemical and Microbiological Properties, Page, A.L., R.H. Miller and D.R. Keeney (Eds.). ASA, Madison, WI., USA., pp: 595-624.

Chapman, H.D., 1965. Cation Exchange Capacity. In: Methods of Soil Analysis, Black, C.A. (Ed.). Part 11, Incorporate Publisher, Madison, Wisconsin, pp: 891-901.

Hunters, A.H.J., 1975. Laboratory and Greenhouse techniques for nutrient survey to determine the soil amendments required for optimum plant growth. Raleigh North Carolina.
Jackson, M.L., 1970. Nitrate-Nitrogen. Soil Chemical Analysis. 6th Edn., Prentice Hall Incorporation, Englewood Cliffs, New York, pp: 326-330.

Lombin, L.G., 1974. Assessment of the magnesium potential of some Nigerian soils. Ph.D. Thesis, Agronomy Department, University of Ibadan, Nigeria.

Murdock, G.I., G. Ojo-Atere, E.I. Colborne, E.I. Olomo and E.M. Odugbesan, 1976. Soils of the Western State Savanna in Nigeria/Land Resources Division. Ministry Oversea Development, England, ISBN: 0902409484.

Murphy, J. and J.P. Riley, 1962. A modified single solution method for the determination of phosphate in natural waters. Anal. Chim. Acta, 27: 31-36.

Mylavarapus, R.S. and D.E. Kennelley, 2002. UF/IFAS Extension Soil Testing Laboratory (ESTL): Analytical Procedures and Training Manual. Institute of Food and Agricultural Sciences, Gainesville, USA., pp: 28.

Nelson, D.W. and L.E. Sommers, 1982. Total Carbon Organic Matter. In: Methods of Soil Analysis Part 2, Page, A.L., R.H. Miller and D.R. Keeney (Eds.). 2nd Edn., American Society of America, Madison, Wisconsin, pp: 539-579.

Olsen, S.R. and L.E. Sommers, 1982. Phosphorus. In: Page, A.1., R.H. Miller and D.R. Keeney (Eds.). Method of Soil Analysis, Part 2, Chemical and Microbiology Properties, American Society of Agronomy, Madison, pp: 403-430.

Onwueme, I.C. and T.D. Sinha, 1991. Field Crop Production in Tropical Africa (Principles and Practice). Technical Centre for Agricultural and Rural CoOperation CTA, Ede, Wageningen, The Netherlands.

Sobulo, R.A. and O.A. Osiname, 1981. Soils and fertilizer use in Western Nigeria. Int. Agric. Res. Train. Res. Bull., 11: 13-13.

Soil Survey Staff, 1999. Soil Taxonomy: A Basic System of Soil Classification for Making and Interpreting Soil Survey. 2nd Edn., USDA, Washington, DC., pp: 869.

Terry, D.R., E.U. Doku, O.B. Arene and N.M. Mahungu, 1984. Tropical Root crops Production and uses in Africa. International Development and Research Centre, Ottawa, Canada.

Thomas, G.W., 1982. Exchangeable Cations: Methods of Soil Analysis Part 2. In: Chemical and Microbiological Properties, Page, A.L., R.H. Miller and D.R. Keeney (Eds.). 2nd Edn., Agronomy Monograph 9, ASA and SSSA, Madison, WI., pp: 159-165.

Udoh, D.J., B.A. Ndon, P.E. Asuquo and N.U. Ndaeyo, 2005. Crop Production Techniques for the Tropics. Concept Publications Limited, Lagos, Nigeria, pp: 464. 